\title{
Analisis Pengembangan Objek Wisata Celebes Canyon Kabupaten Barru
}

\author{
Analysis of the Development of Celebes Canyon Tourism Objects Barru Regency \\ Rusneni Ruslan', Jumardy ${ }^{1}$, Kamran Aksa ${ }^{1,2}$ \\ ${ }^{1}$ Program Studi Perencanaan Wilayah \& Kota, Fakultas Teknik,Universitas Bosowa Makassar \\ ${ }^{2}$ Program Studi Pascasarjana Perencanaan Wilayah dan Kota, Fakultas Teknik, Universitas Bosowa Makassar \\ Email : rusneni@universitasbosowa.ac.id
}

\section{Artikel info}

Artikel history:

Diterima; 08-03-2021

Direvisi: 19-04-2021

Disetujui; 19-04-2021

\author{
Keywords: \\ Analysis of tourism \\ development strategy
}

\begin{abstract}
The purpose of this study is to identify the contributing factors to the undevelopment of Celebes Canyon attractions and to formulate a strategy direction for the development of Celebes canyon attraction in Barru Regency. This study uses multiple Liniear Regression analysis methods and and Descriptive Analysis methods. Based on the results of the analysis there are several factors that affect the undeveloped attraction Celebes Canyon. The main conclusions of the analysis of multiple linear regressions in which tourist attractions, tourist attractions, tourist attractions, promotions and information and accessibility greatly influence the undeveloped attractions of Celebes Canyon. The results showed that there is a remarkable beauty felt by visitors who visit celebes canyon attractions, especially in its natural panorama and katrs rocks that are only obtained in Celebes Canyon tourism. But for, to expand it is necessary strategy, namely pengeleloa must make use of vacant land, optimize facilities and infrastructure and add tourist traction so that Celebes Canyon tourism can compete with other wista objects.
\end{abstract}

\begin{abstract}
Abstrak. Tujuan dari penelitian ini adalah untuk mengidentifikasi faktorfaktor penyebab belum berkembangnya objek wisata Celebes Canyon dan untuk merumuskan arahan strategi pengembangan objek wisata Celebes canyon di Kabupaten Barru.Penelitian ini menggunakan metode analisis Regresi Liniear Berganda dan dan metode Analisis Deskriptif. Berdasarkan hasil analisis terdapat beberapa faktor yang mempengaruhi tidak berkembang nya objek wisata Celebes Canyon. Kesimpulan utama dari hasil analisis regresi linear berganda di mana daya tarik wisata, sarana wisata, perasarana wisata, promosi dan informasi dan aksebilitas sangat berpengaruh terhadap tidak berkembang nya objek wisata Celebes Canyon. Hasil Penelitian menunjukkan bahwa ada keindahan yang sangat luar biasa yang dirasakan oleh pengunjung yang berkunjung ke objek wisata Celebes Canyon, terutama pada panorama alam nya dan bebatuan katrs yang hanya didapat di wisata Celebes Canyon. Namun untuk, untuk mengembangka maka di butuhkan strategi, yaitu pengeleloa harus memanfaatkan lahan yang kosong, mengoftimalkan sarana dan prasarana dan melakukan penambahan antraksi wisata agar wisata Celebes Canyon mampu bersaing dengan objek wista yang lain.
\end{abstract}

Coresponden author: Email: Jumardicrez14@gmail.com

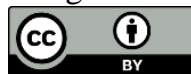

artikel dengan akses terbuka dibawah lisensi CC BY -4.0

\section{PENDAHULUAN}

Dalam Undang - Undang Nomor 10 tahun 2009 tentang kepariwisataan, di nyatakan bahwa : "Parwisata adalah berbagai macam kegiatan wisata dan didukung berbagai fasilitas serta layanan yang di sediakan oleh masyarakat, pengusaha dan pemerintah daerah" Salah satu tujuan mendasar yang ingin dicapai negara berkembang seperti Indonesia saat ini adalah tercapainya suatu pertumbuhan ekonomi yang kuat dan berdaulat. Usaha keparawisataan merupakan salah satu sub-sektor pembangunan yang secara terus menerus diupayakan pengembangannya secara efisien dan efektif, agar dapat di berdayagun sebagai salah satu sektor andalan kegiatan 
perekonomian nasional dan daerah. Berkembangnya kegiatan pariwisata di suatu daerah akan memberikan pengaruh pada sektor ekonomi serta mendorong pembangunan sektor - sektor lainnya, khususnya dalam hal ini memperluas lapangan pekerjaan dan peluang untuk berusaha. Penerimaan devisa dan pendapatan daerah dari sub sektor pariwisata masih belum memenuhi terget yang diharapkan, sehingga peran serta pemerintah dunia usaha dan masyarakat masih terus di tuntut peran aktifnya.

Indonesia menyimpan harapan besar pada sektor parwisata yang di harapkan mampu menunjang perekonomian dan pembangunan baik skala lokal maupun nasional.Dalam pelaksanaan otonomi daerah melalui Undang Undang Nomor 23 tahun 2014 tentang Pemerintah Daerah, maka diberikan kewenangan dan tanggung jawab penuh kepada pemerintah daerah dari pemerintah pusat untuk dapat mengatur daerahnya untuk mengembangkan potensi - potensi daerah, untuk menunjang pelaksanaan pemerintahan, pembangunan dan pembinaan kemasyarakataan.

Salah satu kewenangan tersebut adalah melalui sektor parwisata, sektor ini dapat berperan besar dalam meningkatkan pendapatan asli daerah, karena pada setiap daerah memiliki daya tarik pengunjung. Pemerintah Daerah berperan penting dalam mempengaruhi daya tarik tempat wisatanya, tergantung bagaimana peran pemerintah mengelola dan mengembangkan potensi tempat wisatanya.

Kabupaten Barru adalah salah satu nama Kabupaten yang ada di Indonesia bagian tengah Provensi Sulawesi Selatan Kotamadya Makassar, Kabupaten Barru berada pada jalur trans Sulawesi dan merupakan daerah lintas wisata yang terletak sebelah utara Makassar, sebelah utara Barru berbatasan dengan Kota madya Pare-Pare, sebelah timur berbatasan dengan Kabupaten Soppeng dan Kabupaten Bone. Sehingga jika di perhatikan secara geografis letaknya sangat strategis, serta merupakan salah satu Kabupaten yang berada dalam Kawasan pembangunan ekonomi terpadu. Kabupaten Barru memiliki potensi obyek wisata yang cukup banyak dan variatif, baik berupa wisata alam, wisata pantai/bahari dan wisata budaya/sejarah. Keberadaan obyek wisata sebagai sebuah potensi yang prospektif mengacu pada dukungan infrastruktur yang tersedia, posisi wilayah sebagai daerah transit, dan kebijakan pemerintah daerah dalam menarik investasi. Pengembangan sektor kepariwisataan sangat diperlukan karena akan memberikan multipliter effect antara lain dapat memperluas lapangan kerja, mengembangkan ekonomi lokal dan berbagai sektor terikat.

Celebes Canyon merupakan salah satu tempat wisata. Secara administrasi Celebes Canyon terletak di desa Libureng Kecamatan Tanete Riaja Kabupaten Barru.Calebes Canyon adalah satu dari kecantikan alam Sulawesi Selatan berupa aliran air dengan bebatuan eksotis di sekelilingnya yang menjadi surga bagi para pemburu tempattempat indah. Adapun kegiatan yang bisa dinikmati dan dilakukan saat berkunjung ke obyek wisata alam Celebes Canyon antara lain berkemah, bermain air atau berphoto dengan background yang indah. Selain itu, Celebes Canyon juga berhasil meraih posisi juara 2 pada ajang lomba Anugrah Pesona Indonesia yang dilaksanakan oleh kementrian Parwisata Repoblik Indonesia diuntuk kategori tujuan wisata baru.Destinasi wisata Celebes Canyon kian hari semakin terlihat peningkatan destinasi dalam hal pengunjung. Hal ini dibuktikan dengan makin eksisnya tempat wisata ini di berbagai akun media sosial namun pengelolaan kawasan wisata dan sumber daya manusia yang masih kurang maksimal seperti masih kurang nya fasilitas pendukung wisata juga berdampak pada rendahnya realisasi pendapatan retrebusi objek wisata tersebut. Terbatasnya dana yang diberikan oleh pemerintah membuat akses jalan menuju lokasi wisata yang masih belum memadai serta masih banyak lahan kosong yang dapat di manfaatkan juga menjadi faktor yang menyebabkan para wisatawan lokal kesulitan untuk menjangkau lokasi wisata Celebes Canyon di Kabupaten Barru. Selain itu, partisipasi masyarakat dan tingkat Pendidikan khususnya warga yang tinggal di sekitaran obyek wisata Celebes Canyon yang masih rendah di karenakan kurang kesadaran warga sekitar akan manfaat yang bisa diperoleh jika pemanfaatan dan pengembangan potensi wisata tersebut dioptimalkan, terutama dengan merawat kondisi wisata tersebut seperti menjaga kebersihan dan ketertiban di lokasi tersebut. Hal ini tentunya membutuhkan kerjasama antara pihak warga desa dan pemerintah daerah yang bertugas mengelola potensi daerah khususnya bidang pariwisata.

Agar pengembangan wisata Celebes Canyon dapat memberikan manfaat sebesar - besarnya bagi pembangunan, maka peneliti merasa penting untuk meneliti tentang Analisis Pengembangan Objek Wisata Celebes Canyon. Sehingga pelaksanaanya dibutuhkan arahan dan strategi yang terencana guna menarik wisatawan dan menambah pendapatan Kabupaten Barru khususnya di daerah Celebes Canyon.

\section{METODE}

\subsection{Jenis Penelitian}

Penelitian ini mencoba membahas tentang bagaimana kondisi objek wisata Celebes Canyon di kabupaten barru dan bagaimana strategi pengembangan objek Wisata Celebes Canyon di kabupaten barru. 


\subsection{Lokasi dan Waktu Penelitian}

Lokasi penelitian ini berada pada Kabupaten Barru tepatnya di Kecamatan Tanete Riaja, Desa Libureng yang di mana desa tersebut manjadi salah satu jalur menuju Kabupaten Soppeng sehingga Objek Wisata tersebut memiliki lokasi yang sangat strategis, di tambah dengan jarak dari kota Barru ke lokasi Obyek Wisata Celebes Canyon juga sangat tidak jauh. Secara ruang lingkup penelitian, penelitian tidak di lakuakan di seluruh wilayah kecamatan Tanete Riaja tetapi terpokus hanya pada lokasi objek wisata Celebes Canyon. Hal ini di lakukan dengan tujuan untuk memperkecil lingkup wilayah penelitian dengan mengefisienkan waktu yang ada sehingga penelitian ini dapat di lakukan dengan maksimal.

Waktu penilitian dilakukannya proses penyusunan tugas akhir dengan judul Analisis Strategi pengembangan Obyek Wisata Celebes Canyon di Kabupaten barru ini adalah mulai pada tanggal 25 pebruari sampai dengan 25 juni 2020.

\subsection{Jenis dan Sumber Data}

\subsubsection{Jenis Data}

Dalam penelitian ini, data yang digunakan yaitu data kuantitatif dan kualitatif. Menurut Supratiknya (2015). Data kuantitatif adalah data yang bisa diselidiki secara langsung dan bisa dihitung dengan menggunakan cara yang mudah sedangkan data kualitatif adalah data yang berbentuk bukan angka atau menjelaskan secara deskripsi tentang kondisi lokasi penelitian secara umum.

\subsubsection{Sumber Data}

Kemudian untuk sumber data peneliti menggunakan sumber data primer dan sumber data sekunder:

2.3.2.1 Data primer yaitu data yang diperoleh secara langsung melalui pengamatan langsung ke lapangan atau lokasi penelitian, data primer yang dibutuhkan antara lain data kondisi lapangan dan pandangan pengunjung terhadap kondisi wisata Celebes canyon

2.3.2.2 Data sekunder yaitu data yang diperoleh melalui dokumen-dokumen resmi menyangkut penelitian ini yang didapatkan dari berbagai instansi terkait seperti data jumlah penduduk, data aspek fisik dasar yang di dapatkan dari Badan Pusat Statistik (BPS) Kabupaten Barru dan Dinas Parwisata Kabupaten Barru.

Tabel 1.Sumber Data Penelitian

\begin{tabular}{|c|c|c|c|c|}
\hline No & Jenis Data & Sumber Data & Teknik Pengumpulan Data & Tempat Perolehan Data \\
\hline 1 & $\begin{array}{l}\text { Data distribusi dan luas wilayah } \\
\text { Objek Wisata Celebes Canyon }\end{array}$ & Data Primer & $\begin{array}{c}\text { Survey Wawancara dan } \\
\text { Obsevasi Lapangan }\end{array}$ & $\begin{array}{l}\text { Badan Pusat Statistik } \\
\text { Kabupaten Barru }\end{array}$ \\
\hline 2 & $\begin{array}{l}\text { Data kependudukan Kabupaten } \\
\text { Sinjai dan kawasan perkotaan } \\
\text { Sinjai }\end{array}$ & Data Sekunder & Survey Data Sekunder & $\begin{array}{l}\text { Badan Pusat Statistik } \\
\text { Kabupaten Barru }\end{array}$ \\
\hline 3 & $\begin{array}{l}\text { Data jenis dan delinasi objek } \\
\text { wisata Celebes Canyon }\end{array}$ & $\begin{array}{c}\text { Data Primer dan } \\
\text { Sekunder }\end{array}$ & $\begin{array}{l}\text { Observasi Lapangan dan } \\
\text { Interprestasi Peta Citra } \\
\text { Satelit }\end{array}$ & $\begin{array}{c}\text { Data Lapangan, Citra Satelit SASPlanet, } \\
\text { dan Citra Satelit Google Earth Tahun } \\
2020\end{array}$ \\
\hline 4 & $\begin{array}{l}\text { Dokumen RTRW Kabupaten } \\
\text { Barru beserta database shepfile }\end{array}$ & Data Sekunder & Survey Data Sekunder & BAPEDA Kabupaten Barru \\
\hline 5 & $\begin{array}{l}\text { Dokumen RDTR kabupaten } \\
\text { Barru }\end{array}$ & Data Sekunder & Survey Data Sekunder & BAPEDA Kabupaten Barru \\
\hline
\end{tabular}

\subsection{Populasi dan Sampel}

\subsubsection{Popilasi}

Populasi merupakan wilayah generalisasi yang terdiri atas obyek/subyek yang mempuyai kualitas dan karakteristik tertentu yang di tetapkan oleh peneliti untuk dipelajar. Sesau dengan judul tugas akhir, maka yang menjadi populasi dari penelitian adalah penduduk yang berada di Desa Libureng dan juga masyarakat di sekitaran Obyek Wisata Celebes Canyon.

\subsubsection{Sampel}

Sampel adalah bagian dari jumlah karakterristik yang dimiliki oleh populasi yang diteliti.Sampel yang baik adalah sampel yang bersifat representatif atau yang dapat menggambarkan karakteristik populasi secara menyeluruh terkait dengan judul penelitian dalam penyusunan tugas akhir ini, teknik sampling yang digunakan yaitu nonprobability dengan teknik purposive sampling,

Teknik purposive sampling adalah teknik untuk menentukan sampel penelitian dengan beberapa pertimbangan tertentu yang bertujuan agar data yang diperoleh nantinya bisa lebih representative.(Mukhsin et al., n.d.) Alasan menggunakan teknik purposive sampling adalah karena tidak semua sampel memiliki kriteria yang 
sesuai dengan fenomena yang diteliti. Oleh karena itu, penulis memilih teknik purposive sampling yang menetapkan pertimbangan-pertimbangan atau kriteria-kriteria tertentu yang harus dipenuhi oleh sampel-sampel yang digunakan dalam penelitian ini. Adapun banyaknya jumlah sampel dalam penelitian ini akan ditentukan dengan menggunakan rumus slovin.

Teknik Slovin menurut Sugiyono (2011:87) dalam (Pradana \& Reventiary, 2016) menetapkan rumus Slovin dalam menentukan Sampel adalah sebagai berikut:

$$
n=\frac{N}{1+N e^{2}}
$$

Dimana :

$n$ : jumlah sampel

$\mathrm{N}$ : jumlah populasi

e: batas toleransi kesalahan (error tolerance) 1\%, 10\% dan $15 \%$

Dalam penelitian ini untuk tingkat kesalahan dalam penarikan sampel akan digunakan persentase sebesar 5\%, dan untuk lebih jelasnya mengenai jumlah sampel dalam penelitian ini adalah sebagai berikut:

sebagai berikut:

$$
\begin{aligned}
& \mathrm{n}=\mathrm{N} /(1+\mathrm{N} .(\mathrm{e}) 2) \\
& \mathrm{n}=80 /(1+80 .(0,5) 2) \\
& \mathrm{n}=80 / 1,2 \\
& \mathrm{n}=66,6 \text { (dibulatkan menjadi } 67)
\end{aligned}
$$

Dari hasil perhitungan diatas dapat disimpulkan bahwa jumlah sampel yang akan digunakan dalam penelitian ini sebagai perwakilan dari keseluruhan populasi adalah sebanyak 67 jiwa responden yang berasal dari pengunjung yang datang ke objek Celebes Canyon.

\subsection{Metode Analisis}

\begin{tabular}{|c|c|c|c|c|}
\hline No & Variabel Penelitian & & Devinisi Operasional & Indikator Penelitian \\
\hline 1 & Daya tarik wisata & $\mathrm{X} 1$ & $\begin{array}{l}\text { Menurut Cooper dkk (1995). Daya tarik wisata } \\
\text { merupkan segala sesuatu yang menarik dan } \\
\text { bernilai untuk di kunjungi. (Khotimah, n.d.) }\end{array}$ & $\begin{array}{l}\text { - Antraksi Alam } \\
\text { - Antraksi Buatan } \\
\text { - Antraksi Budaya }\end{array}$ \\
\hline 2 & Sarana Wisata & $\mathrm{X} 2$ & $\begin{array}{l}\text { Menurut Suwantoro (1997) Sarana wisata } \\
\text { adalah hal - hal yang kebradaannya } \\
\text { berhubungan dengan usaha dan kebutuhan } \\
\text { sarana lainnya yang membuat wisatawan lebih } \\
\text { banyak datang.(Imam, n.d.) }\end{array}$ & $\begin{array}{l}\text { - Lahan Parkir } \\
\text { - Tempat Sampah } \\
\text { - Rumah Makan }\end{array}$ \\
\hline 3 & Prasarana Wisata & $\mathrm{X} 3$ & $\begin{array}{l}\text { Menurut Suwantoro (2004). Prasarana Wisata } \\
\text { adalah sumber daya alam dan sumber daya } \\
\text { manusia yang mutlak di butuhkan oleh } \\
\text { wisatawan dalam perjalanannya didaerah tujuan } \\
\text { wisata.(Imam, n.d.) }\end{array}$ & $\begin{array}{l}\text { - Listrik } \\
\text { - Air } \\
\text { - Telkomonikasi }\end{array}$ \\
\hline 4 & Informasi dan Promosi & $\mathrm{X} 4$ & $\begin{array}{l}\text { Menurut Mc Daniel (1998). Promosi adalah } \\
\text { komonikasi dari para penjual yang } \\
\text { mengimpormasikan Informasi dan promosi } \\
\text { pariwisata dilakukan guna menarik wisatawan } \\
\text { dari berbagai daerah maupun mancanegara } \\
\text { untuk berkunjung (Budiharja, 2016) }\end{array}$ & $\begin{array}{l}\text { - Media Promosi } \\
\text { - Bentuk Promosi } \\
\text { - Tanggapan Tentang } \\
\text { Objek Wisata }\end{array}$ \\
\hline 5 & Aksebilitas & $\mathrm{X} 5$ & $\begin{array}{l}\text { Menurut Sunaryo (2013). Aksebilitas } \\
\text { dimaksudkan sebagai segenap sarana yang } \\
\text { memberikan kemudahan kepada wisatawan } \\
\text { untuk mencapai suatu destinasi maupun tujuan } \\
\text { wisata terkait. (Darmawan \& Nurhidayati, } \\
\text { 2019) }\end{array}$ & $\begin{array}{l}\text { - Ketersediaan Jaringan } \\
\text { Jalan } \\
\text { - Biaya Transportasi } \\
\text { - Jarak Dan Waktu } \\
\text { Tempuh }\end{array}$ \\
\hline 6 & $\begin{array}{l}\text { Perkembangan Objek } \\
\text { Wisata }\end{array}$ & & & \\
\hline
\end{tabular}

Metode analisis yang digunakan untuk menjawab tiga tujuan penelitian dalam penelitian ini, terdapat dua analisis yaitu analisis linear berganda dan analisis deskriptif kualitatif. yang dimana tujuan penelitian, variabel yang digunakan dan keluaran dari analisis tersebut, lebih jelasnya dapat dilihat pada tabel berikut:

Tabel 2. Variabel Penelitian 


\section{HASIL DAN PEMBAHASAN}

\subsection{Hasil}

\subsubsection{Gambaran Umum Lokasi Penelitian}

Secara astronomis Kabupaten Barru terletak diantara 4o 05' 49" LintangSelatan - 4o 47' 35" Lintang Selatan dan 119o 35' 00" Bujur Timur - 119o 49' 16" Bujur Timur. Secara administrasi Kabupaten barru memiliki batas batas wilayah yaitu

- Sebelah Utara:Kota Pare - Pare dan Kab. SidrapC

- Sebelah Timur:Kabupaten Soppeng dan Kabupaten Bone.

- Sebelah Selatan:Kabupaten Pakajenne Kepulauan

- Sebelah Barat:Selat Makassar.

Luas wilayah Kabupaten Barru seluas 1.174,72 Km2, terbagi dalam 7 Kecamatan yaitu Kecamatan Tanete Riaja, Kecamatan Tanete Rilau, Kecamatan Barru, Kecamatan Soppeng Riaja, Kecamatan Mallusetasi, Kecamatan Pujananting, dan Kecamatan Balusu.

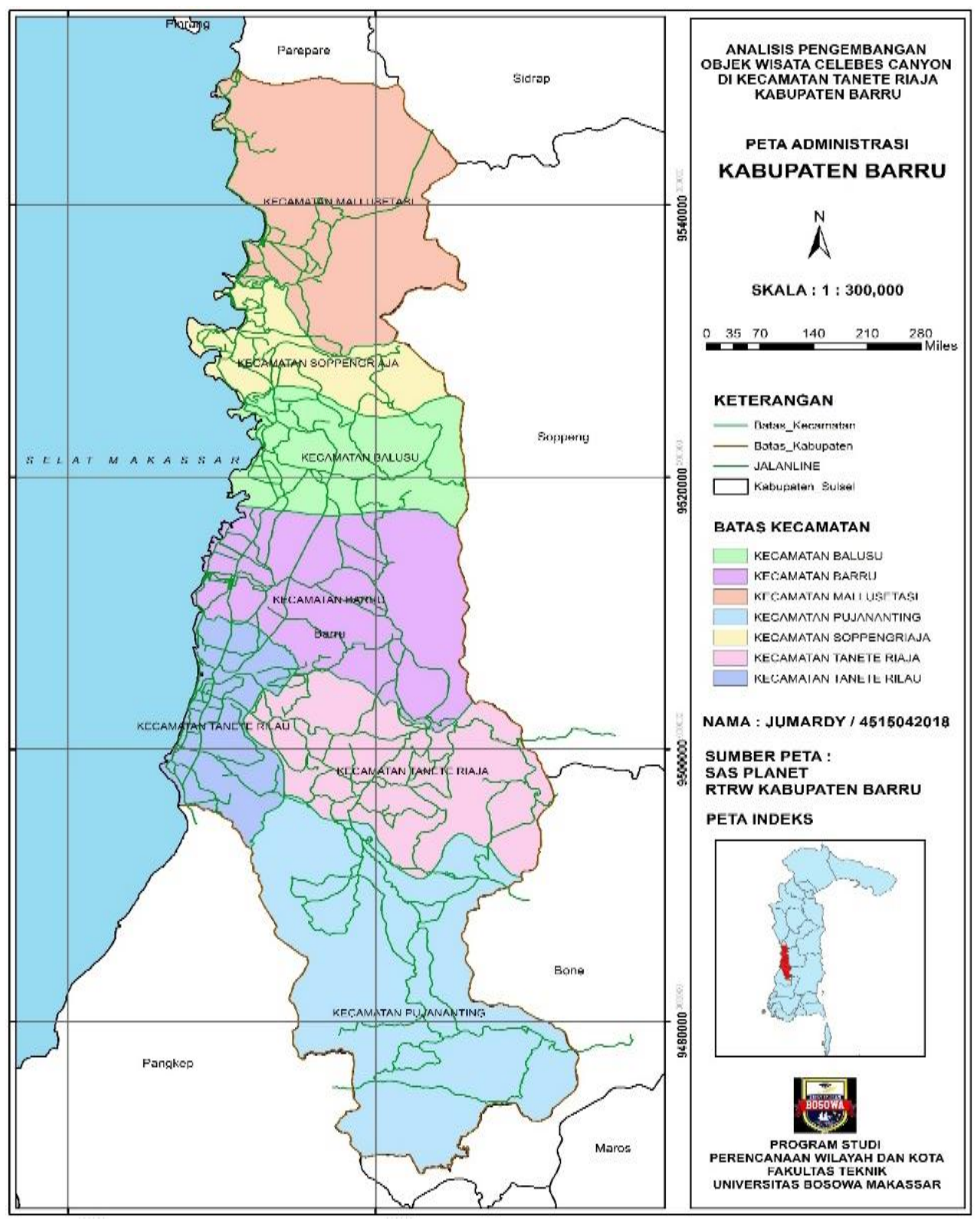

Gambar 1 Peta Administrasi Kabupaten Barru 


\subsubsection{Kondisi Topografi dan Kemeringan Lereng}

Kabupaten Barru mempunyai ketinggian antara 0-1.700 meter diatas permukaan air laut (mdpl), dengan bentuk permukaan sebagian besar daerah kemiringan, berbukit hingga bergunung - gunung. Wilayah bertopografi perbukitan hingga pengunungan berada disebahagiaan besar wilayah tengah hingga timur dan selatan yang sebagiannya juga merupakan Kawasan karst. Sebahagiaanya lainya merupakan daerah datar landai hingga pesisir. Kabupaten Barru merupakan daerah pesisir pantai yang cukup Panjang. Garis pantai mencapai $87 \mathrm{~km}$ sehingga merupakan Kabupaten dengan pesisir pantai terpanjang di Sulawesi Selatan.

Bentang wilayah Kabupaten Barru yang merupakan wilayah datar, bergelombang, berbukit sampai bergunung yang hamper memenuhi seluruh Kabupaten Barru. Secara umum jenis tanah yang tersebar di wilayah Kabupaten Barru adalah Alluvial, Litosol, Regosol, Mediteran yang tersebar di semua kecamatan.

\subsection{Pembahasan}

\subsubsection{Gambaran Umum Lokasi Penelitian}

\subsubsection{Delinasi Lokasi Penelitian Objek Wisata Celebes Canyon}

Secara administrasi lokasi penelitian objek wisata Celebes canyon terdapat di Kabupaten Barru, Kecamatan Tanete Riaja, Desa Libureng. Secara fungsional objek wisata Celebes Canyon ditetapkan sebagai kawasan objek wisata dalam recana induk pengembangan pariwisata daerah (RIPDA) Kabupaten Barru. Secara geografis objek wisata Celebes Canyon ini merupakan objek wisata air yang terdapat di Sungai Ulle dengan karakteristik mempunyai bebatuan karts sebagai daya tarik utama. Dalam penelitian ini, peneliti menggunakan batasan alam dan batasan buatan atau bentukan aktivitas manusia dalam menentukan batasan deleniasi lokasi penelitian. Peneliti menggunakan batasan delinasi tersebut dengan dasar pertimbangan bahwa kawasan objek wisata Celebes Canyon ini belum memiliki batasan yang ditetapkan oleh pemerintah daerah Kabupaten Barru. Dari hasil penentuan deliniasi yang telah ditentukan oleh peneliti, didapati bahwa luas delineasi lokasi penelitian adalah sebesar 1,986 ha.

Dari aspek penggunaan lahan pada lokasi penelitian secara eksistin diominasi oleh penggunaan lahan padi ladang, dikarenakan sekitar Objek Wisata Celebes Canyon banyak terdapat lahan pertanian dan perkebunan masyarakat. Lahan tersebut juga memberikan pemandangan yang sangat indah sebagai daya tarik penunjang perkembangan Wisata Celebes Canyon.

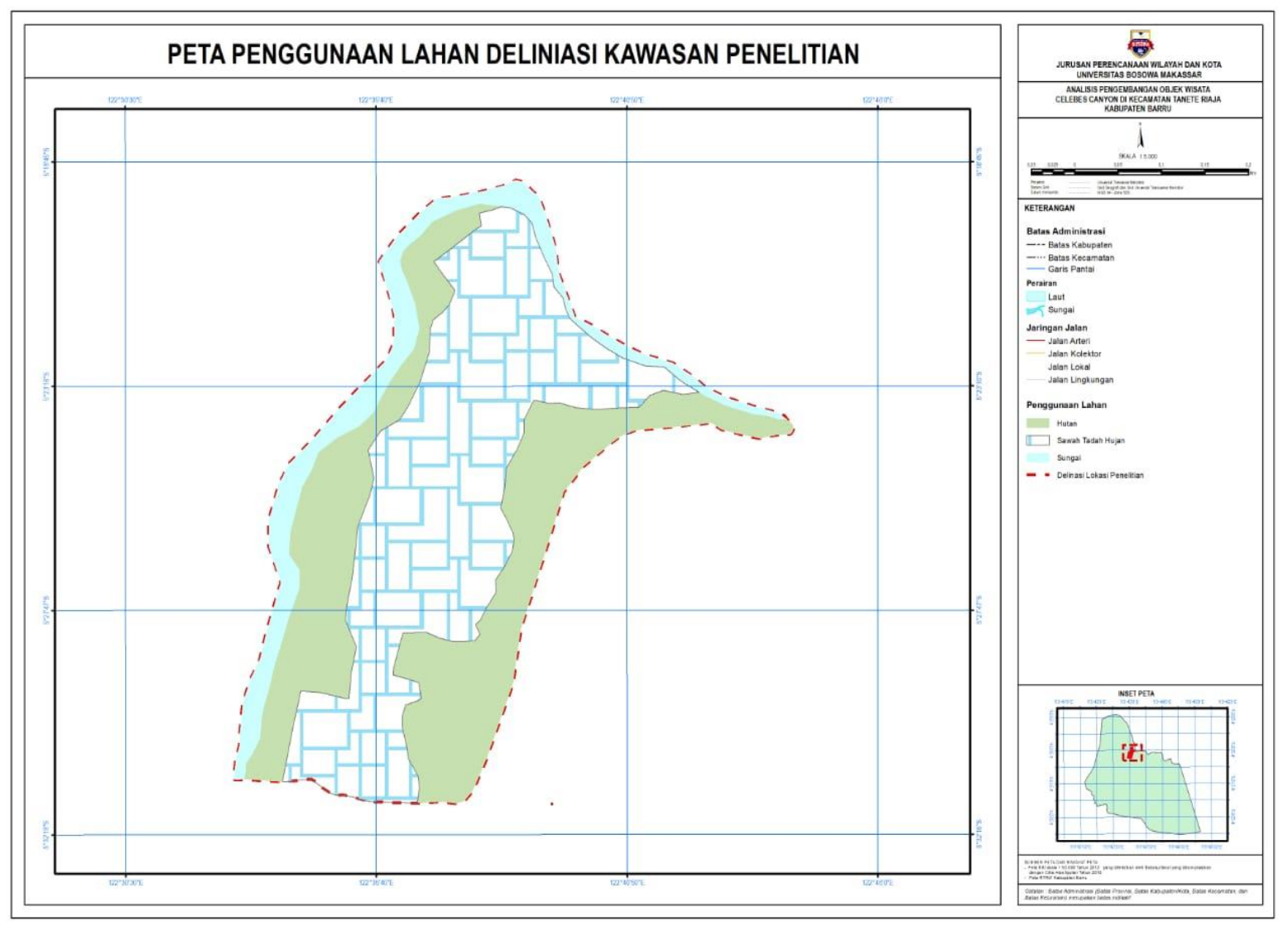

Gambar 2. Peta Penggunaan Lahan Deleniasi Kawasan Penelitian 


\subsubsection{Profil Objek Wisata Celebes Canyon}

\subsubsection{Daya Tarik Wisata}

Antraksi wisatawan merupakan salah satu daya tarik wisatawan terhadap lokasi wisata yang akan menarik para wisatawan untuk berkunjung ke objek wisata Celebes Canyon. Objek wisata Celebes canyon memberikan panorama alam yang sangat indah untuk di nikmati seperti hamparan tebing karts putih dan coklat yang menjadi daya tarik wisatawan untuk berkunjung ke tempat wisata tersebut, selain susunan tebing karts pengunjung juga bisa melakukan aktifitas lainnya seperti pengunjung juga bisa melakukan aktifitas berenang di karenakan terdapat beberapa kolam renang yang terbentuk dari susunan tebing.

Adapun daya tarik lainnya ketika kita berkunjung ke objek wisata Celebes Canyon yaitu kita bisa melakukan kegiatan berkema di sekitaran aliran sungai karna lokasi tersebut juga sangat bangus di gunakan untuk berkemah, selain berkemah pengunjung juga bisa melakukan river tubing atau menghayut dengan ban pelampung mengikuti aliran sungai juga memberikan sensasi yang baru kepada pengunjung. Akan tetapi tidak semua pengunjung melakukan river turbing di karenakan pengunjung lebih tertarik dengan panorama alam yang di sajikan oleh objek Wisata Celebes Canyon sehingga para pengunjung lebih melakukan aktivitas seperti berphoto dan duduk di atas batu - batu aliran sungai sambil menikmati suara aliran air dan keindahan batu karts.

\subsubsection{Sarana Wisata}

Sarana sosial dalam pengembangan Objek Wisata merupakan penunjang yang sangat penting harus di sediakan pada kawasan perwisata adapun sarana sosial yang harus di sediakan seperti MCK atau toiliet, peribadatan, dan tempat sampah. Adapun sarana sosial yang saat ini telah ada di lokasi obyek wisata yaitu MCK atau toilet dan tempat sampah akan tetapi tidak berfungsi dengan baik di karenakan masyrakat yang mengelola tidak memperhatikan sarana sosial tersebut seperti MCK atau toilet yang ada di lokasi tidak berfungsi pada semestinya di karenakan jarang nya ketersediaan air bersih sehingga pengunjung jarang menggunakan toilet tersebut. Adapun fasilitas lain seperti penyediaan tempat sampah juga masih sangat kurang hanya ada di beberapa titik saja sehingga pengunjung yang datang kadang menyimpan sampah nya di tempat mereka bersantai di karenakan kurang nya titik tempat sampah yang di sediakan sehingga tempat wisata tersebut menjadi kotor di akibatkan ulah pengunjung tersebut.

\subsubsection{Prasarana Wisata}

Jaringan jalan merupakan salah satu jaringan yang sangat menunjang perkembangan suatu objek yang berfungi sebagai penghubung antar pusat kegiatan pada kawasan wisata.

Untuk pengembangan jaringan jalan, pola jaringan yang sudah ada akan menjadi acuan untuk pengembangan jaringan jalan selanjutnya, karena melihat eksistensi jalan yang ada pada lokasi pengembangan Wisata Celebes Canyon masih belum sepenuh nya baik apalagi kondisi jalan masuk kelokasi sangat kurang baik dinkarenakan kondisi jalan yang masih berlubang, tanah dan bebatuan sehingga para pengunjung harus berhati - hati jika berjalan masuk ke dalam objek wisata.

Dalam pengembangan parwisata, listrik juga sangat dibutuhkan untuk mendukung kegiatan wisata. Jaringan listrik di objek wisata Celebes Canyon belum memadai di karenakan belum adanya tiang listrik di area wisata Celebes Canyon, sehingga kebutuhan jaringan listrik belum terpenuhi di karenakan pengelola hanya mengambil arus listrik dari rumah warga terdekat, maka dari itu pemerintah juga harus terlibat dalam hal ini agara kebutuhan jaringan listrik dapat terpenuhi.

Dalam pengembangan wisata jaringan air sangat penting di mana untuk memenuhi kebutuhan air bersih bagi pengunjung parwisata Celebes Canyon, akan tetapi pemenuhan air bersih masih belum memadai dikarenakan air dalam WC (toilet) masih sering kosong sehingga kebutuhan pengunjung tidak terpenuhi, maka dari itu pengelolaan objek wisata elebes canyon harus di pertingkat terlebih pada jaringan air bersih sebagai salah satu penunjang pengembangan objek wisata Celebes Canyon.

Jaringan telkomonikasi juga sangat berpengaruh dalam perkembangan objek wisata Celebes Canyon. Jaringan telkomonikasi di objek wisata Celebes Canyon masih kurang baik dikarenakan kondisi di lokasi masih tidak terdapat jaringan dikarenakan di sekitaran area lokasi tidak terdapat tower jarigan sehingga kebutuhan pengunjung dalam hal ini telkomonikasi belum terpenuhi sehingga perlu dibangun kan tower telkomonikasi agar pengembangan objek wisata dapat berkembang.

\subsubsection{Informasi dan Promosi}

Dalam pengembangan objek wisata media informasi juga sangat penting dalam pengembangan objek wisata dikarenakan salah satu carah untuk menarik wisatawan datang berkunjung ke objek wisata Celebes Canyon dengan media informasi yang mereka dapat dengan daya tarik yang ada di objek wisata tersebut.

Para pengunjung mengetahui objek wisata Celebes Canyon mereka dapatkan dari teman terdekat yang sudah terlebih dahulu berkunjung ke objek wisata tersebut, sehingga informasi terkait Celebes Canyon masih banyak yang belum mengetahui sehingga di butuhkan informasi yang lebih luas agar dapat menarik para pengunjung 
sehingga jumlah pengunjung objek wisata Celebes Canyon dapat meningkat. Dalam pengembangan suatu objek wisata media promosi sangat perlu dilakukan, dengan daya tarik yang berikan oleh objek wisata Celebes Canyon berupa bebatuan karts dan keindahan alam yang sangat alami yang tidak dimiliki oleh objek wisata lain yang mampu menarik wisatawan untuk berkunjung ke objek wisata tersebut.

\subsubsection{Aksebilitas}

Ketersedian jaringan jalan di lokasi objek wisata Celebes Canyon sudah memadai dan mampu di tempuh dengan kendaraan roda 2 alam artian motor dan roda 4 dalam artian mobil, akan tetapi permukaan jaringan jalan tersebut belum sepenuh nya baik dikarenakan masih banyak perukaan jalan menuju objek wisata dalam keadaan berlobang atau kurang baik sehingga menghambat pengunjung dan dapat meyebabkan kecelakaan bagi pengunjung yang ingin menuju ke objek wisata.

\subsubsection{Faktor - Faktor yang menyebabkan Sehingga Objek Wisata Celebes Canyon Belum Berkembang}

\subsubsection{Uji Kualitas Data}

Tujuan dari uji kualitas data adalah untuk mengetahui konsistensi dan akurasi data yang dikumpulkan. Uji kualitas data yang dihasilkan dari penggunaan instrument penelitian dapat dianalisis dengan menggunakan uji validitas dan uji reliabilitas

a. Uji Validitas

Uji Validitas adalah prosedur untuk memastikan apakah kuesioner yang akan dipakai untuk mengukur variabel penelitian valid atau tidak. Untuk mengetahui item pernyataan itu valid dengan melihat nilai Corrected Item Total Corelation. Apabila item pernyataan mempunyai $r$ hitung $>$ dari $r$ tabel maka dapat dikatakan valid. Pada penelitian ini terdapat jumlah sampel $(n)=67$ responden dengan $r$ tabel $=0,197$. Jadi, item pernyataan yang valid mempunyai $r$ hitung lebih besar dari 0,197 . Adapun hasil uji validitas data dalam penelitian ini dapat dilihat pada tabel berikut:

Tabel 3. Hasil Uji Validitas

\begin{tabular}{|c|c|c|c|c|}
\hline Variabel & Item1 & R Hitung & R Tabel & Keterangan \\
\hline \multirow[t]{3}{*}{ Daya Tarik Wisata } & $\mathrm{X} 1.1$ & 0,808 & 0,2404 & Valid \\
\hline & $\mathrm{X} 1.2$ & 0,818 & 0,2404 & Valid \\
\hline & $\mathrm{X} 1.3$ & 0,701 & 0,2404 & Valid \\
\hline \multirow[t]{3}{*}{ Sarana Wisata } & $\mathrm{X} 2.1$ & 0,785 & 0,2404 & Valid \\
\hline & $\mathrm{X} 2.2$ & 0,677 & 0,2404 & Valid \\
\hline & $\mathrm{X} 2.3$ & 0,811 & 0,2404 & Valid \\
\hline \multirow[t]{3}{*}{ Prasarana Wisata } & $\mathrm{X} 3.1$ & 0,753 & 0,2404 & Valid \\
\hline & $\mathrm{X} 3.2$ & 0,825 & 0,2404 & Valid \\
\hline & $\mathrm{X} 3.3$ & 0,756 & 0,2404 & Valid \\
\hline \multirow[t]{3}{*}{ Informasi dan Promosi } & $\mathrm{X} 4.1$ & 0,831 & 0,2404 & Valid \\
\hline & $\mathrm{X} 4.2$ & 0,763 & 0,2404 & Valid \\
\hline & $\mathrm{X} 4.3$ & 0,808 & 0,2404 & Valid \\
\hline \multirow[t]{3}{*}{ Aksebilitas } & $\mathrm{X} 5.1$ & 0,700 & 0,2404 & Valid \\
\hline & $\mathrm{X} 5.2$ & 0,784 & 0,2404 & Valid \\
\hline & $\mathrm{X} 5.3$ & 0,776 & 0,2404 & Valid \\
\hline \multirow{3}{*}{$\begin{array}{c}\text { Perkembangan Objek } \\
\text { Wisata }\end{array}$} & Y.1 & 0,801 & 0,2404 & Valid \\
\hline & Y.2 & 0,728 & 0,2404 & Valid \\
\hline & Y.3 & 0,835 & 0,2404 & Valid \\
\hline
\end{tabular}

Sumber: Data primer diolah (2020) 
Tabel diatas menunjukkan bahwa seluruh item pernyataan memiliki nilai koefisien korelasi positif dan lebih besar dari pada r-tabelo, 197. Hal ini berarti bahwa data yang diperoleh telah valid dan dapat dilakukan pengujian data lebih lanjut

b. Uji Rebialitas

Uji reliabilitas digunakan untuk mengukur suatau kuesioner yang merupakan indikator dari variabel atau konstruk. Uji reliabilitas data dilakukan dengan menggunakan metode Alpha Cronbach yakni suatu instrumen dikatakan reliabel bila memiliki koefisien keandalan reabilitas sebesar 0,60 atau lebih. Hasil pengujian reliabilitas data dapat dilihat pada tabel berikut:

Tabel 4. Hasil Uji Realibilitas

\begin{tabular}{cccc}
\hline No & Variabel & Cronbach' Alpha & Keterangan \\
\hline 1. & Daya Tarik Wisata & 0,665 & Reliabel \\
2. & Sarana Wisata & 0,632 & Reliabel \\
3. & Prasarana Wisata & 0,674 & Reliabel \\
4. & Informasi dan Promosi & 0,719 & Reliabel \\
5. & Aksebilitas & 0,617 & Reliabel \\
6. & Perkembangan Objek Wisata & 0,695 & Reliabel \\
\hline
\end{tabular}

Sumber: Data primer diolah (2020)

Tabel diatas menunjukkan bahwa nilai cronbach's alpha dari semua variabel lebih besar dari 0,60, sehingga dapat disimpulkan bahwa instrumen dari kuesioner yang digunakan untuk menjelaskan keseluruhan variabel, yaitu dinyatakan handal atau dapat dipercaya sebagai alat ukur variabel.

\subsubsection{Asumsi Klasik}

a. Uji Normalistis

Uji normalitas dilakukan untuk melihat apakah nilai residual terdistribusi normal atau tidak. Uji statistik yang dapat dilakukan yaitu pengujian one sample kolmogorov-smirnov. Suatu persamaan regresi dikatakan normal apabila nilai signifikansi uji Kolmogorov-Smirnov lebih besar dari 0,05. Hasil uji kolmogorov smirnov dapat dijelaskan pada tabel dibawah in:

Tabel 5. Hasil Uji Normalitas - One Sample Kolmogorov-Smirnov

\begin{tabular}{ccr}
\hline & & Unstandardized \\
& & Residual \\
\hline $\mathrm{N}$ Normal Parameters ${ }^{\mathrm{a}, \mathrm{b}}$ & & 607 \\
& Mean &, 0000000 \\
Most Extreme & Std. Deviation &, 68235031 \\
Differences & Absolute &, 079 \\
& Positive &, 055 \\
Kolmogorov-Smirnov Z & Negative &,- 079 \\
Asymp. Sig. (2-tailed) & &, 648 \\
\hline
\end{tabular}

Sumber: output SPSS 21 (2020)

Berdasarkan tabel diatas menunjukkan bahwa hasil tabel normalitas yang ditunjukkan oleh Asymp sig diperoleh angka 0,795 yang lebih besar dari 0,05. Hal ini menunjukkan bahwa data berdistribusi normal.

b. Uji Multikonlinearitas

Uji multikolinearitas bertujuan untuk menguji apakah model regresi ditemukan adanya korelasi antar variabel bebas (independen). Syarat pengujian multikolinearitas adalah jika nilai tolerance $>0,10$ dan VIF $<10$, maka dapat diartikan bahwa tidak terdapat multikolinearitas pada penelitian tersebut. 
Tabel 6.Hasil Uji Multikolinearitas

\begin{tabular}{|c|c|c|c|}
\hline & \multicolumn{2}{|c|}{ Collinearity Statistics } \\
\hline \multicolumn{2}{|c|}{ Model } & Tolerance & \\
\hline \multirow{5}{*}{1} & \multirow{2}{*}{$\begin{array}{l}\text { Daya Tarik Wisata } \\
\text { Sarana Wisata }\end{array}$} & ,728 & VIF \\
\hline & &, 524 & 1,910 \\
\hline & Prasarana Wisata &, 547 & 1,830 \\
\hline & Informasi dan Promosi &, 722 & 1,385 \\
\hline & Aksebilitas &, 593 & 1,686 \\
\hline
\end{tabular}
Sumber: Output SPSS 21 (2020)

Berdasarkan hasil pengujian pada tabel diatas, nilai VIF untuk semua variabel memiliki nilai lebih kecil daripada 10, sedangkan nilai tolerance yang juga menunjukkan nilai yang lebih besar dari 0,1. Hal ini menunjukkan bahwa data dalam penelitian ini tidak terjadi gelaja multikolinearitas.

c. Uji Heteroskedastistas

Uji heteroskedastisitas bertujuan menguji apakah dalam model regresi terjadi ketidaksamaan variance dari residual satu pengamatan ke pengamatan yang lain. Untuk mendeteksi adanya heterokedastisitas dapat dilakukan dengan menggunakan uji glejser. Jika nilai signifikansi lebih besar dari 0,05 maka tidak terjadi heteroskedastisitas. Hasil uji heteroskedastisitas dapat dijelaskan pada tabel dibawah ini:

Tabel 7.Hasil Uji Heteroskedastisitas - Uji Glejser

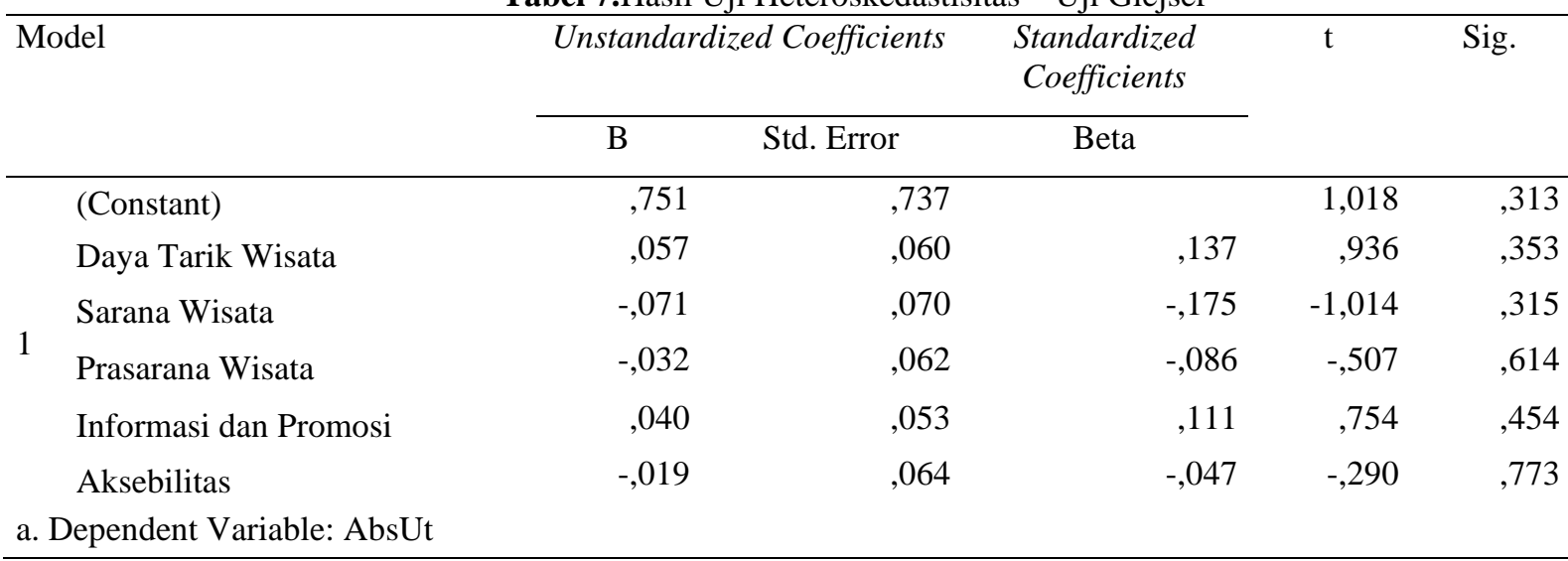

Sumber: Output SPSS 21 (2020)

Hasil uji Glejser pada tabel di atas, dapat diketahui bahwa probabilitas untuk semua variabel independen tingkat signifikansinya diatas tingkat kepercayaan 0.05. Jadi dapat disimpulkan bahwa model regresi tidak mengandung adanya heteroskedastisitas.

d. Hasil Uji Hipotesis

Teknik analisis yang digunakan untuk menguji hipotesis menggunakan analisis regresi berganda dengan meregresikan variabel independen terhadap variabel dependen, Uji hipotesis ini dibantu dengan menggunakan program SPSS versi 21.

\subsubsection{Koefisien Determinasi}

Uji koefisien deteminasi digunakan untuk mengetahui seberapa besar kemampuan variabel bebas (independen) dalam menerangkan variabel terikat (dependen).

Tabel 8.Hasil Uji Koefisien Determinasi $\left(\mathrm{R}^{2}\right)$

\begin{tabular}{lrrrrr}
\hline Model & $\mathrm{R}$ & \multicolumn{2}{c}{ R Square } & Adjusted R Square & Std. Error of the Estimate \\
\hline 1 &, $837^{\text {a }}$ &, 700 &, 676 &, 70976 \\
\hline
\end{tabular}

a. Predictors: (Constant), Aksebilitas, Daya Tarik Wisata , Informasi dan Promosi , Prasarana Wisata, Sarana Wisata

Sumber: Output SPSS 21 (2020)

Hasil uji koefisien determinasi menunjukkan nilai R2 (Adjusted R Square) dari model regresi sebesar 0,676, hal ini berarti bahwa 70\% yang menunjukkan bahwa perkembangan objek wisata dipengaruhi oleh variabel daya tarik wisata, sarana wisata, prasarana wisata, informasi dan promosi, aksebilitas. Sisanya sebesar $30 \%$ dipengaruhi oleh variabel lain yang tidak diteliti dalam penelitian ini. 


\subsubsection{Uji Simultan}

Uji simultan digunakan untuk mengetahui pengaruh secara bersama-sama antara variabel independen terhadap variabel dependen. Hasil uji simultan dapat dijelaskan pada tabel dibawah ini:

Tabel 9.Hasil Uji F - Uji Simultan

\begin{tabular}{|c|c|c|c|c|c|}
\hline Model & Sum of Squares & $\mathrm{df}$ & Mean Square & $\mathrm{F}$ & Sig. \\
\hline Regression & 71,778 & 5 & 14,356 & 28,496 &, $000^{\mathrm{b}}$ \\
\hline 1 Residual & 30,730 & 61 &, 504 & & \\
\hline Total & 102,507 & 66 & & & \\
\hline
\end{tabular}

- a. Dependent Variable: Perkembangan Objek Wisata

b. Predictors: (Constant), Aksebilitas, Daya Tarik Wisata, Informasi dan Promosi , Prasarana Wisata,

Sarana Wisata

Sumber: Output SPSS 21 (2020)

Berdasarkan tabel diatas dapat dilihat bahwa dalam pengujian regresi berganda menunjukkan hasil $\mathrm{F}$ hitung sebesar 28,496 dengan tingkat signifikansi 0,000 yang lebih kecil dari 0,05, di mana nilai $\mathrm{F}$ hitung 28,496 lebih besar dari nilai $F$ tabelnya sebesar 2,37. Berarti variabel daya tarik wisata, sarana wisata, prasarana wisata, informasi dan promosi, aksebilitas secara bersama-sama berpengaruh terhadap perkembangan objek wisata

\subsubsection{Uji Parsial}

Uji parsial digunakan untuk menguji hipotesis secara parsial guna menunjukkan pengaruh tiap variabel independen secara individu terhadap variabel dependen. Hasil uji parsial dapat dijelaskan pada tabel dibawah ini:

Tabel 10.Hasil Uji T - Uji Parsial

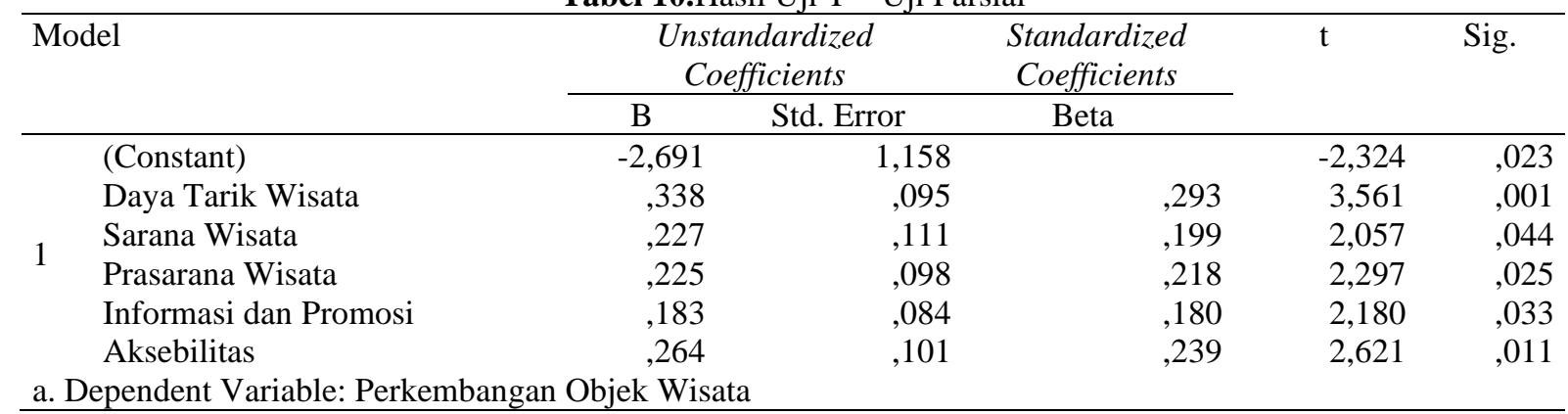

\section{Sumber: output SPSS 21 (2020)}

Kemudian pengaruh terhadap variabel independen secara individu terhadap variabel dependen. Untuk lebih jelasnya mengenai nilai koefisien beta pengaruh variabel $\mathrm{X} 1, \mathrm{X} 2, \mathrm{X} 3, \mathrm{X} 4$, dan $\mathrm{X} 5$ terhadap variabel $\mathrm{Y}$ adalah sebagaimana diuraikan pada gambar berikut. Hasil uji parsial dapat dilihat pada diagram berikut;

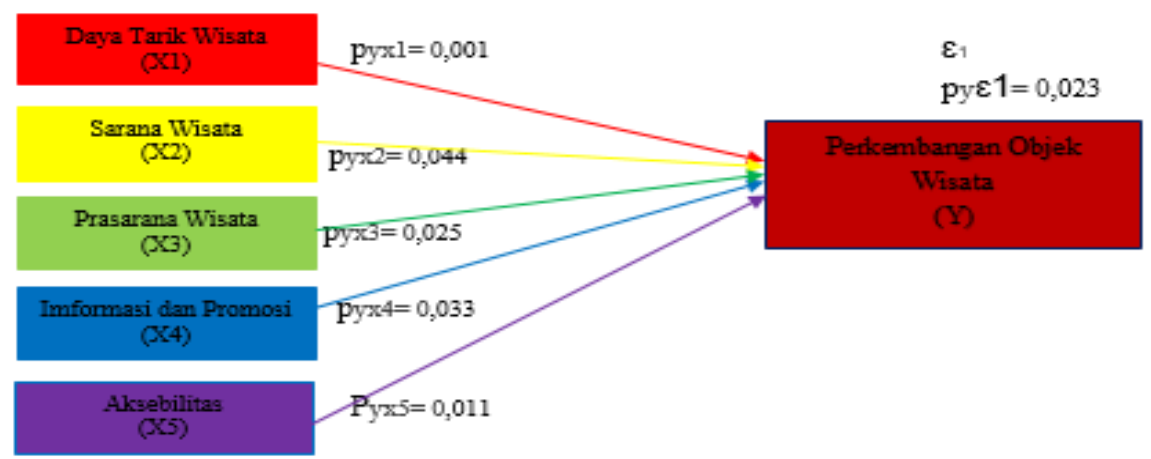

Gambar 3. Model Pengaruh Variabel Dependen Terhadap Variabel Indepedent

Berdasarkan tabel diatas dapat dianalisis model estimasi sebagai berikut :

$Y=-2,691+0,338 X 1+0,227 X 2+0,225 X 3+0,183 X 4+0,264 X 5+e$

Hasil interpretasi atas hipotesis penelitian yang diajukan dapat dilihat sebagai berikut:

a. Daya tarik wisata berpengaruh terhadap objek wisata berdasarkan pada tabel 4. 20 Dapat dilihat bahwa variabel kondisi vegetasi memiliki $\mathrm{t}$ hitung sebesar 3,561 > t tabel 1,9996 dengan koefisien beta unstandardized sebesar 0,338 dan tingkat signifikansi 0,001 yang lebih kecil dari 0,05, maka H1 diterima. Hal ini berarti daya tarik wisata berpengaruh positif dan signifikan terhadap perkembangan objek wisata. 
b. Seperti yang kita ketahui bahwa daya tarik wisata merupakan salah satu penunjang pengembangan parwisata akan tetapi ada 3 indikator yaitu antraksi alam, antraksi buatan dan antraksi budaya, sehingga dalam objek wisata Celebes Canyon yang perlu di kembangkan untuk menunjang pengembangan wisata yaitu antraksi alam seperti pemerluasan lahan batu karts sehingga para pengunjung lebih bebas untuk melakukan rekreasi ataupun mengespor lokasi objek wisata dan adapun antraksi buatan yang harus di lakukan yaitu penambahan spot photo dan juga lokasi untuk arum jerang ataupun berkemah.

c. Sarana wisata berpengaruh terhadap perkembangan objek wisata

Dapat dilihat bahwa variabel kondisi vegetasi memiliki thitung sebesar 2,057 > t tabel 1,9996 dengan koefisien beta unstandardized sebesar 0,227 dan tingkat signifikansi 0,044 yang lebih kecil dari 0,05, maka $\mathrm{H} 2$ diterima. Hal ini berarti sarana wisata berpengaruh positif dan signifikan terhadap perkembangan objek wisata.

Salah satu faktor penyebab tidak berkembang nya objek wisata dikarenakan kurang optimalnya pengelolaan sarana wisata, sehingga dalam pengembangan objek wisata Celebes Canyon perlu di optimalkan sarana seperti gazebo, lahan parkir, toilet, tempat sampah dan penambahahn rumah makan untuk penunjang ekonomi masyarakat di sekitar objek wisata Celebes.

d. Prasarana wisata berpengaruh terhadap perkembangan objek wisata

Dapat dilihat bahwa variabel kondisi vegetasi memiliki thitung sebesar 2,297 > t tabel 1,9996 dengan koefisien beta unstandardized sebesar 0,225 dan tingkat signifikansi 0,025 yang lebih kecil dari 0,05, maka H3 diterima. Hal ini berarti prasarana wisata berpengaruh positif dan signifikan terhadap perkembangan objek wisata.

Salah satu faktor yang berpengaruh terhadap perkembangan objek wisata Celebes Canyon adalah prasarana wisata sehingga perlu adanya perbaikan prasarana seperti jalan dan adapun yang harus di sediakan seperti listrik, air, telkomonikasi di karenakan belum adanya sarana tersebut di lokasi objek wisata Celebes canyon .

e. Informasi dan promosi berpengaruh terhadap perkembangan objek wisata

Berdasarkan tabel 4.20infi dapat dilihat bahwa variabel kondisi vegetasi memiliki $\mathrm{t}$ hitung sebesar 2,180 > t tabel 1,9996 dengan koefisien beta unstandardized sebesar 0,183 dan tingkat signifikansi 0,033 yang lebih kecil dari 0,05, maka H4 diterima. Hal ini berarti informasi dan promosi berpengaruh positif dan signifikan terhadap perkembangan objek wisata.

Faktor informasi dan promosi juga perlu di tingkatkan dikarenakan jumlah pengunjung akan meningkat jika informasi terkait Celebes Canyon lebih luas sehingga perlu adanya perluasan informasi dan memperbanyak promosi terkait keindahan objek wisata Celebes Canyon.

f. Aksebilitas berpengaruh terhadap perkembangan objek wisata

dapat dilihat bahwa variabel kondisi vegetasi memiliki t hitung sebesar 2,621 > t tabel 1,9996 dengan koefisien beta unstandardized sebesar 0,264 dan tingkat signifikansi 0,011 yang lebih kecil dari 0,05, maka H5 diterima. Hal ini berarti aksebilitas berpengaruh positif dan signifikan terhadap perkembangan objek wisata.

Salah satu penyebab tidak berkembanganya objek wisata jika ketersediaan jaringan jalan, jarak dan waktu tempuh, dan biaya transportasi tidak optimalkan di karenakan pada jaringan jalan menuju lokasi Celebes canyon tidak cukup baik sehingga berdampak pada waktu tempuh maka dalam hal ini harus di adakan perbaikan pada kondisi jalan sehingga para pengunjung dapat melakukan perjalanan dengan nyaman dan aman untuk sampai di lokasi objek wisata Celebes canyon.

\subsubsection{Penentuan Zonasi Kawasan Wisata Celebes Canyon}

Pengalokasian masing - masing ruang kawasan di fokuskan pada penetuan komponen aktifitas sarana dan prasarana wisata serta melakukan upaya pengendalian ruang pada area kawasan yang wajib di lindungi dengan tatanan aktifitas bangunan yang dapat di padukan dengan kondisi lahan yang di miliki. Dalam keseluruhan luas kawasan ini direncanakan pengembangannya berbanding $30 \%$ yang terbangun dan $70 \%$ yang merupakan kawasan hijau yang perlu di jaga dan di lestarikan.

Pertimbangan yang di lakukan dalam pengalokasiaan ruang adalah radius pencapaian dan skala pelayanan. Untuk komponen kegiatan aktifitas utama kawasan yang berfungsi untuk melayani seluruh kawasan, di mana rencana struktur tata ruang kawasan akan di lakukan dengan cara menempatkan zona kegiatan utama di kawasan berada pada kawasan yang memiliki hamparan tebing karts putih dan coklat, kemudian di tambah dengan keindahan alam yang ada di sekitar tebing menjadi zona kawasan pendukung. Fasilitas pendukung akan tersebar sesuai dengan fungsi masing - masing zona kegiatan. Pola ini di terapkan agar tercipta hierarki ruang yang dapat menciptakan kondisi yang nyaman.

Berdasarkan karakteristik yang di miliki masing-masing lokasi, maka dalam penataan kawasan objek wisata celebe canyon ini di asarkan pada pembagian zoning kawasan. Adapun arahan penetapan kawasan Objek Wisata Celebes canyon sebagai berikut: 
a. Zona inti

Rencana pengembangan zona inti ini tidak akan terlepas dari hasil analisa peneliti dan arahan konsep pengembangan sebagaimana yang sudah di bahas pada bab - bab sebelumnya. Rencana pengembangan zona inti yang di maksudkan memuat tentang segala bentuk kegiatan - kegiatan yang mampu menunjang fungsi utama dari zona inti ini. Adapun muatan kegiatan - kegiatan yang di laksanakan dalam pengembangan zona inti ini, yaitu pengembangan saran dan prasarana utama penunjang zona inti, dan pengembangan tempat untuk beristirahat. Dari berbagai jenis kegiatan yang di kembangkan dalam zona inti tersebut akan di turunkan juga terkait dengan segala bentuk sarana dan prasarana penunjang yang akan di bangun dalam zona inti ini.

Adapun sarana dan prasaran tersebut yaitu:

- Pembangunan Gazebo

- Penambahan tempat sampah

- Pembangunan mushollah

- Pembangunan area parkir

b. Zona penyangga

Rencana pengembangan zona penyangga yang dimaksudkan memuat tentang segala bentuk kegiatan - kegiatan yang mampu menunang fungsi utama dari zona penyangga ini dan mendukung pengembangan wisata Celebes canyon sebagai objek wisata.

Adapun muatan kegiatan - kegiatan yang di laksanakan dalam pengembangan zona penyangga ini disesuaikan dengan fungsinya yang sebagai penunjang dan tidak akan menganggu serta tumpan tindi dengan fungsi zona lainnya khususnya zona inti sehingga keberadaan zona penunjang ini tidak akan merusak kondisi dan keaslian dari objek wisata Celebes canyon.

Adapun untuk rencana muatan kegiatan - kegiatan yang akan di kembangkan dalam zona penyangga ini, yaitu pengembangan sarana dan prasarana pendukung zona penyangga, pengembangan dan pemeliharaan kondisi lingkungan fisik dan kawasan pemukiman eksisting, serta peningkatan kualitas sumber daya masyrakat melalui pemberdayaan.

- Mempertahan kan keberadaan pemukiman local

- Membangun klinik kesehatan

- Memperbaiki jalan

- Membangun spot photo
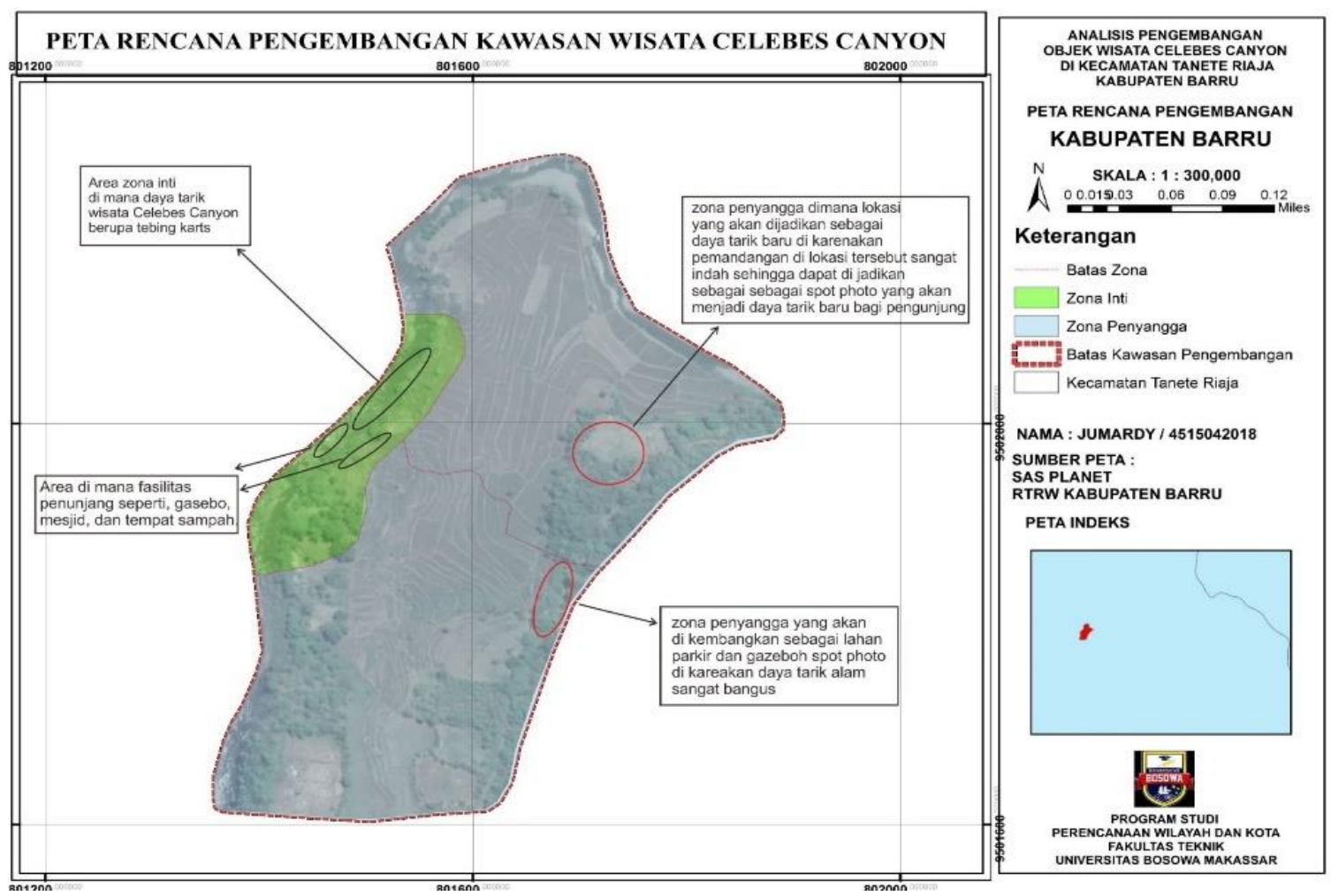

Gambar 4.Peta Rencana Pengembagan Kawasan Wisata Celebes Canyon 


\subsubsection{Arahan Pengembangan Kawasan Wisata Celebes Canyon}

Arahan pengembangan kawasan wisata Celebes canyon bertujuan agar dapat menunjang pengembangan kawasan tebing karts tersebut serta mengoptimalkan kawasan Objek Wisata Celebes Canyon yang berada di Desa liburen Kecamatan Tanete Riaja Kabupaten Barru.

Agar dapat mencapai arahan tersebut, di perlukan pengoptimalan potensi-potensi yang ada pada kawasan mangrove dan lingkungan sekitarnya baik pengembangan secara sosial maupun secara fisik terkait dengan sarana dan prasarana untuk menunjang parwisata tebing karts di Celebes Canyon.

Sesuai dengan teori - teori yang sebelumnya bahwa permintaan dan penawaran akan sangat mempengaruhi perkembangan kawasan wisata itu sendiri, oleh karena itu dari hasil analisis yang telah di lakukan permintaan dan penawaran yang ada di lokasi penelitian sudah sangat memenuhi untuk dikembangkan menjadi sebuah kawasan Wisata tebing karts Celebes Canyon yang berada di Kabupaten Barru

Kawasan inti dari wisata ini yaitu lebih mengoptimalkan panorama alam dan lebih memperluas area tebing karts yang ada di sepanjang aliran sungai dan juga menambah sarana prasarana yang masih kurang, memperkaya atau memperbanyak kegiatan wisata sebagai daya tarik wisata untuk tinggal lebih lama di lokasi wisata, memberikan informasi keadaan alam di sekitar lokasi serta mengampanyekan gerakan sadar wisata ( lingkungan alam) serta mengikutsertakan masyrakat dalam memelihara keamanan dan kenyamana pengunjung.

Kawasan penyangga dari wisata ini yaitu Menambah daya tarik wisata buatan sebebagi pelengkap atau daya tarik tambahan/variatif alam penataan dan pengembangan daya tarik lainnya, sehingga dalam pengembangan melekat pada objek wisata tersebut. Misalnya membuat daya tarik wisata kuliner di lahan yang msih kosong atau wisata agro seperti sawah yang sdekat dengan objek wisata dapat di nikmati tanpa adanya kompensasi atau bayaran. Pemandangan yang gratis tetunya dapat merupakan bagian tambahan atau sisipan dalam wisata untuk meningkatkan apresiasi wisatawan

\section{KESIMPULAN}

Berasarkan hasil penelitian ini maka dapat di simpulkan sebagai berikut : 1) Faktor - faktor yang mempengaruhi tidak berkembang nya Objek wisata Celebes Canyon Desa Libureng meliputi faktor daya tarik wisata dimana belum tersedianya antraksi buatan dan antraksi budaya, faktor sarana wisata seperti gazebo, lahan parkir, toilet, dan tempat sampah belum memadai, faktor prasarana wisata seperti listrik, air, dan telkomonikasi juga belum tersedia, faktor informasi dan promosi masih perlu ditingkatkan dan faktor aksesbilitas seperti ketersediaan jaringan jalan, waktu tempuh dan biaya transportasi perlu dioptimalkan dengan baik . 2) Arahan strategi pengembangan objek wisata Celebes Canyon terdiri dari 3 alternatif yaitu, Melakukan promosi dan informasi kepada publik terhadap objek wisata Celebes Canyon. Menawarkan paket - paket atau antraksi buatan seperti sphot photo, tempat cemping, dan River turbing menggunakan ban pelampung agar pengunjung dapat betahan lebih lama di objek wisata. Memanfaatkan lahan kosong untuk di jadikan tempat usaha seperti rumah makan bagi masyarakat sekitar sebagai penunjang pengembangan wisata Celebes Canyon.

Berdasarkan kesimpulan yang telash di uraikan maka saran yang di dapat di berikan adalah : 1) Objek Wisata Celebes Canyon harus di manfaatkan secara oftimal dengan berdasarkan daya dukung lingkungan, sarana serta prasarana di sekitar objek wisata perlu di bangun dan pengembangan nya harus bertujuan untuk menata sungai sehingga dapat mempertahan kan potensi wisata yang ada dan bermanfaat bagi semua orang serta dapat mengurangi kerusakan lingkungan. 2) Perlu adanya kerja sama antara stakeholders guna mewujukan kemitraan yang serasi dalam pengembangan dan pengelolaan objek wisata Celebes Canyon. 3) Menigkatkan kualitas SDM baik dari pengelola maupun masyarakat sangat perlu diperlukan baik secara formal maupun informal karena SDM sangat penting dalam menunjang pengembangan objek wisata Celebes Canyon.

\section{DAFTAR PUSTAKA}

Supratiknya, A. 2015. "Penerbit Universitas Sanata Dharma." 177.

Budiharja, G. E. (2016). Pengaruh Kualitas Produk, Harga, Promosi Dan Brand Image Terhadap Keputusan Pembelian Produk Aqua Di Kota Pati. 8(2), 30.

Darmawan, J., \& Nurhidayati, H. (2019). Strategi Pengembangan Kampung 99 Pepohonan Sebagai Daya Tarik Wisata Edukasi Di Kota Depok. Journal Of Tourism Destination And Attraction, 7(1), 34-46. Https://Doi.Org/10.35814/Tourism.V7i1.784

Imam, I. (N.D.). Pengembangan Wilayah Wisata Banyu Panas Desa Palimanan Kabupaten Cirebon. 28.

Khotimah, K. (N.D.). Strategi Pengembangan Destinasi Pariwisata Budaya. 10.

Mukhsin, R., Mappigau, P., \& Tenriawaru, A. N. (N.D.). Pengaruh Orientasi Kewirausahaan Terhadap Daya Tahan Hidup Usaha Mikro Kecil Dan Menengah Kelompok Pengolahan Hasil Perikanan Di Kota Makassar. 6. 
Pradana, M., \& Reventiary, A. (2016). Pengaruh Atribut Produk Terhadap Keputusan Pembelian Sepatu Merek Customade (Studi Di Merek Dagang Customade Indonesia). 6, 10.

Undang-Undang Republik Indonesia. (2009). Tentang Kepariwisataan (No 10 Tahun 2009). Sekretariat Negara : Indonesia

Undang-Undang Republik Indonesia. (2014). Tentang Pemerintah Daerah (No 23 Tahun 2014. Sekretariat Negara : Indonesia 